\title{
Alan Feduccia's Riddle of the Feathered Dragons: what reptiles gave rise to birds?
}

\author{
Egbert Giles Leigh Jr
}

Riddle of the Feathered Dragons: Hidden Birds of China, by Alan Feduccia. New Haven, CT: Yale University Press, 2012. Pp. $\mathrm{x}+358$. H/b $\$ 55.00$

This book's author is at home in the paleontology, anatomy, physiology, and behavior of birds. Who could be more qualified to write on their origin and evolution? This book is unusually, indeed wonderfully, well and clearly illustrated: its producers cannot be praised too highly. It is well worth the while of anyone interested in bird evolution to read it. Although it offers no answers to 'where birds came from', it has God's plenty of fascinating, revealing detail, knit together in powerful criticism of prevailing views of bird evolution.

I am new to this book's subject. Cretaceous fossil birds newly reported from northeast China have been decorating the covers of Science and Nature for some years now: this book seemed just the place to learn what these discoveries have told us. And indeed it is, but...

I was blissfully unaware of the raging dispute over just what group of reptiles gave rise to birds. The introduction, which opens with bitter comments on uncritical media hype about dinosaur 'discoveries', and the first chapter, subtitled 'Blame to Go Around', cured me rather brutally of that ignorance. Here, his bitterness (which appears to be justified) overshadowed the birds. Feduccia finally put the birds on center stage in chapter 3, a wonderful account of why Archaeopteryx was an ancestral bird, and the long chapter 4 , his equally wonderful account of the fossils discovered in China, and what they tell us. But the first chapter and its outcrops of bitterness have done their damage, casting a sinister shadow over the rest of the book. Although eager to refute his opponents' arguments, he does so piecemeal, repeatedly returning to the same points. In the end, he fails to marshal his material in a way that effectively conveys what he knows about the early evolution of birds - he is too busy refuting his opponents to tell the story of his birds

Correspondence: bufotyphonius@gmail.com

Smithsonian Tropical Research Institute, Apartado 0843-03092, Balboa, Ancon, Panama, Republic of Panama properly. This is a great pity, for his story is wonderful: his birds would have made a far better focus for this book than the dispute.

So, what is this dispute that spoiled the book? The scientific argument is easily summarized. It started when a paleontologist from Yale University, John Ostrom, unearthed a 75-kg bipedal theropod dinosaur, Deinonychus, buried 110 million years ago in Montana. Deinonychus stood a meter tall, and its tail was $1.5 \mathrm{~m}$ long. It was active: Ostrom thought that both it and Archaeopteryx, which lived 40 million years earlier, were warm-blooded. Deinonychus bore many skeletal resemblances to Archaeopteryx, especially in its forelimbs and pectoral girdle (Ostrom 1975, 1979). True, Archaeopteryx, like the earlier Aurornis (Godefroit et al. 2013), Anchiornis (Hu et al. 2009), and Xiaotingia (Xu et al. 2011), had a robust furcula (wishbone), as do almost all modern flying birds, whereas it is reduced in most flightless birds and entirely lacking in Deinonychus (Ostrom 1979). Archaeopteryx, however, did not have the keeled breastbone and pectoral girdle that is so important for anchoring flight muscles in modern birds. Finally, the hind limbs of Archaeopteryx are more like those of modern birds than are its forelimbs. Figure six in Ostrom (1979) suggest that its feet are more like those of terrestrial than perching birds. Ostrom concluded from these resemblances that Archaeopteryx was cursorial, that feathers first evolved for insulation (Ostrom 1974), and that birds evolved from theropod dinosaurs. Despite the unresolved issue of how a population of runners could evolve powered flight, Ostrom's $(1974,1975,1979)$ case originally seemed formidable.

Feduccia raised three objections to Ostrom's view:

1. Most of the fossils used to support the theropod ancestry of birds are 20 million or more years younger than Archaeopteryx.

2. Theropod dinosaurs, Deinonychus included, were runners. It is much more reasonable to believe that, like bats (Simmons et al. 2008) and pterosaurs

\section{Springer}

(c) 2014 Leigh; licensee Springer. This is an Open Access article distributed under the terms of the Creative Commons Attribution License (http://creativecommons.org/licenses/by/4.0), which permits unrestricted use, distribution, and reproduction in any medium, provided the original work is properly credited. 
(Unwin and Bakhurina 1994), birds descended from arboreal animals that evolved flight via the ability to glide.

3. The fossil record suggests that feathers evolved in connection with gliding and flying, rather than as insulation, or as part of an apparatus for catching insects, as Ostrom $(1974,1979)$ had suggested.

More recently, the tide of evidence has turned strongly against Ostrom's case. The earliest adequately preserved ancestral birds we now know, including Anchiornis (p. 252), and probably Epidendrosaurus, also called Scansiopteryx (pp. 150-154), were four-winged, with some ability for powered flight, unsuited for running on the ground. Archaeopteryx was remarkably reptilian: the fine structure of its wing bones suggests that it was ectothermic (p. 275), but it also flew (pp. 65-66). These animals, however, were not theropods, and probably not dinosaurs at all. Deinonychus (pp. 255-256), feathered dromaeosaurs like Sinornithosaurus (pp. 176-177), and the four-winged, flying Microraptor (pp. 252-254), basal, feathered oviraptosaurs such as Caudipteryx and their descendants (p. 264), and feathered troodontids like Jinfengopteryx (pp. 157-159) indeed share many characteristics with Anchiornis and Archaeopteryx, but they only appeared 30 to 50 million years later (Godefroit et al. 2013, Figure three). In birds, flightlessness has evolved many times from flying ancestors, and some flightless birds, like ostriches and rheas, live in competitive ecosystems well stocked with agile predators. Feduccia (pp. 251-255) is surely right to conclude that many of these 'theropods' are birds descended from flying or gliding ancestors related to Anchiornis and Archaeopteryx.

The discovery that the 'protofeathers' of the bipedal, cursorial theropod Sinosauropteryx (p. 120) were collagen fibers representing various stages of skin decay (Lingham-Soliar et al. 2007) undermined the argument that feathers evolved for purposes other than flight. If Anchiornis and Archaeopteryx were ancestral birds, it would appear that that feathers, which Feduccia shows to be complex, intricate structures well adapted for flight, evolved for that purpose. Feathered wings did not first evolve to be clapped together to catch insects, as Ostrom $(1974,1979)$ had proposed.

Ostrom never accepted Feduccia's counterarguments, but they remained friends who respected each other's views, and whose approaches to paleontological research were similar (p. 236). One must look elsewhere to understand the bitterness in Feduccia's book.

The argument between Feduccia and Ostrom was later engulfed by a methodological one. Before the days of DNA hybridization, Willi Hennig proposed an objective goal for taxonomy: inferring phylogeny - the sequence of speciation events by which a group of related species evolved from their common ancestor (Ridley 1986). This goal has truly Cartesian clarity, distinctness and objectivity - for those organisms where horizontal gene transfer (Woese 2000) is very rare and new species never arise from hybrids of pre-existing species (cf. Mavárez et al. 2006). This goal is now accepted as appropriate for taxonomy, even though its appropriateness was originally contested by no less than Ernst Mayr (Ridley 1986). This goal demands that each taxon should be monophyletic: it should include all the descendants of some common ancestor, and nothing else. Hennig also proposed a methodology for inferring such phylogenies. First, one selects a set of characteristics, whose states can be assessed for each species in the group whose phylogeny is being sought, and which should vary 'independently', as well as a few 'outgroup species' presumed not to share the 'ingroup's' most recent common ancestor. A formal algorithm is then used to deduce the simplest sequence of divergences leading from a common ancestor to the species of the ingroup in question. This method seemed to lend an objective rigor to inferring phylogenies from phenotypic data. Many practitioners of this method proclaim that birds derive from theropod dinosaurs (Forster et al. 1998, Hu et al. 2009, $\mathrm{Xu}$ et al. 2011).

Current methods of inferring phylogenies from phenotypic characteristics are, however, far from robust. One new specimen can cause major changes in the inferred phylogeny (compare Figure two of $\mathrm{Hu}$ et al. 2009, Figure four of Xu et al. 2011, and Figure three of Godefroit et al. 2013). Hu et al. (2009) proclaim Anchiornis a troodontid; $\mathrm{Xu}$ et al. (2011) proclaim it an archaeopterygid.

Cladistic methodology, moreover, is less rigidly objective than it seems. Although (absent horizontal gene transfer and speciation by hybridization) Hennig's goal is objective and unambiguous, using the algorithm for inferring such phylogenies requires subjective judgments ranging from assessing simplicity to selecting appropriate outgroups and characteristics to analyze. To assure that the characters employed vary independently, one must avoid sets of characteristics which co-vary because they are governed by the same gene, or thanks to convergent evolution. In paleontology, cladistic methodology is particularly unreliable if joined with SJ Gould's anti-adaptationist stance (Gould and Lewontin 1979), for only a thorough understanding of adaptation allows us to use the present as a reliable key to the past, and single out likely instances of evolutionary convergence. Conclusions from cladistic methodology - easily misled by close evolutionary convergence (Ridley 1986) - have sometimes been overturned by its more prestigious younger sister, DNA phylogenetics, which is less vulnerable to closely convergent evolution. I vividly remember the shocked disbelief of many biologists when DNA phylogenetics revealed that the tenrecs and shrew-moles of Madagascar were more closely related to elephants than to Eurasian shrews or hedgehogs (Stanhope et al. 1998). 
The initial decisions involved in cladistics analysis benefit greatly from a connoisseur's eye. Feduccia was connoisseur enough to suspect, rightly, that 'protofeathers' on fossil dinosaurs were actually collagen fibers that appear at certain stages of skin decay (LinghamSoliar et al. 2007). This kind of knowledge allows one to distinguish relevant from irrelevant characteristics. Matchless connoisseurship allowed the novelist Nabokov to judge what characteristics were most relevant to classifying lycaenid butterflies. Nabokov (1945) thereby inferred a classification of Neotropical Polyommatus blues, formerly called Plebejinae, without benefit of cladistics technology, and the sequence of invasions from Siberia that populated the New World with these butterflies. Recent DNA phylogenies have resoundingly vindicated his insight (Vila et al. 2011). The importance of such judgments became clear when James and Pourtless (2009), who are not committed to viewing birds as theropods, inferred a phylogeny of the earliest birds and their relatives rather different from the 'theropod-bird' consensus.

More generally, the search for the one objective scientific method, where subjective judgments play no role, is a recipe for ignoring what is crucial. So it was for the psychologists who saw stimulus-response analyses as the way to make animal behavior an objective science by avoiding the subjective world of consciousness. As Changeux (1985, p. 97) remarked, 'Concerned with eliminating subjectivity from scientific observation, behaviorism restricted itself to considering the relationship between variations in the environment (the stimulus) and the motor response that was provoked'. This approach does not let us see that animals have intentions and project their hypotheses onto the external world (Changeux and Ricoeur 2000, p. 42). Is this also true of those cladists who see a particular algorithm for inferring phylogenies from phenotypic data as the one way to practice objective taxonomy? Such methods demand that their practitioners ignore those kinds of data that their methods cannot handle. Indeed, as in the case of scientific Marxism, supposed recipes for objectivity can become dogmas defended with religious zeal (Polanyi 1962, pp. 227-228). Feduccia (p. 2) cites instances of this process among some cladists. This process can discourage interesting science, as did the Roman inquisition of the 17th century (Changeux and Ricoeur 2000, p. 35). Feyerabend's (1975) Against Method is a salutary warning against seeking one scientific method, apt for solving all problems.

In this book, Feduccia opposes his judgment as a connoisseur to paleontologists who appear to have become intellectual prisoners of their cladistic methodology. As reflected in topics ranging from the aerodynamic properties of feathers (pp. 64-65) and the stages of skin decomposition (pp. 130-138) to the role of arrested development in the evolution of flightless birds (pp. 219-220), his book is eloquent testimony to the role of connoisseurship in effective science. For all its bitterness, Feduccia's is a liberating voice, a reminder that methodology should be our servant, not our unquestioned master.

\section{Competing interests}

The author declares that he has no competing interests.

Received: 10 February 2014 Accepted: 18 February 2014

Published online: 11 March 2014

\section{References}

Changeux, JP. (1985). Neuronal man. Princeton, NJ: Princeton University Press. Changeux, JP, \& Ricoeur, P. (2000). What makes us think? Princeton, NJ: Princeton University Press.

Feyerabend, P. (1975). Against method. Thetford: Thetford Press.

Forster, CA, Sampson, SD, Chiappe, LM, \& Krause, DW. (1998). The theropod ancestry of birds: new evidence from the late Cretaceous of Madagascar. Science, 279(5358), 1915-1919.

Godefroit, P, Cau, A, Hu, D-Y, Escuillié, F, Wu, W, \& Dyke, G. (2013). A Jurassic avialan dinosaur from China resolves the early phylogenetic history of birds. Nature, 498(7454), 359-362.

Gould, SJ, \& Lewontin, RC. (1979). The spandrels of San Marco and the Panglossian paradigm: a critique of the adaptationist program. Proceedings of the Royal Society of London, series B, 205(1161), 581-598.

Hu, DY, Hou, L, Zhang, L, \& Xu, X. (2009). A pre-Archaeopteryx troodontid theropod from China with long feathers on the metatarsus. Nature, 461(7264), 640-643

James, FC, \& Pourtless, JA (2009). Cladistics and the origin of birds. A review and two new analyses. Ornithological Monographs, 66(viii), 1-78.

Lingham-Soliar, T, Feduccia, A, \& Wang, X. (2007). A new Chinese specimen indicates that 'protofeathers' in the Early Cretaceous theropod dinosaur Sinosauropteryx are degraded collagen fibers. Proceedings of the Royal Society B, 274(1620), 1823-1829.

Mavárez, J, Salazar, CA, Bermingham, E, Salcedo, C, Jiggins, CD, \& Linares, M. (2006). Speciation by hybridization in Heliconius butterflies. Nature, 441 (7095), 868-871.

Nabokov, V. (1945). Notes on Neotropical Plebejinae (Lycaenidae, Lepidoptera). Psyche, 52(1-2), 1-61.

Ostrom, JH. (1974). Archaeopteryx and the origin of flight. Quarterly Review of Biology, 49(1), 27-47.

Ostrom, JH. (1975). The origin of birds. Annual Review of Earth and Planetary Sciences, 3, 55-77.

Ostrom, JH. (1979). Bird flight: how did it begin? American Scientist, 67(1), 46-56. Polanyi, M. (1962). Personal knowledge. Chicago, IL: University of Chicago Press.

Ridley, M. (1986). Evolution and classification: the reformation of cladism. London: Longman.

Simmons, NB, Seymour, KL, Habersetzer, J, \& Gunnell, JF. (2008). Primitive early Eocene bat from Wyoming and the evolution of flight and echolocation. Nature, 451, 818-821.

Stanhope, MJ, Waddell, VG, Madsen, O, de Jong, W, Hedges, SB, Cleven, GC, Kao, D, \& Springer, MS. (1998). Molecular evidence for multiple origins of Insectivora and for a new order of endemic African insectivore mammals. Proceedings of the National Academy of Sciences, USA, 95(17), 9967-9972.

Unwin, DM, \& Bakhurina, NN. (1994). Sordes pilosus and the nature of the pterosaur flight apparatus. Nature, 371, 62-64.

Vila, R, Bell, CD, Macniven, R, Goldman-Huertas, B, Ree, RH, Marshall, CR, Bálint, Z, Johnson, K, Benyamini, D, \& Pierce, NE. (2011). Phylogeny and palaeoecology of Polyommatus blue butterflies show Beringia was a climate-regulated gateway to the New World. Proceedings of the Royal Society B, 278(1719), $2737-2744$

Woese, C. (2000). Interpreting the universal phylogenetic tree. Proceedings of the National Academy of Sciences, USA, 97(15), 8392-8396.

Xu, X, You, H, Du, K, \& Han, F. (2011). An Archaeopteryx-like theropod from China and the origin of Avialae. Nature, 475(7357), 465-470.

doi:10.1186/s12052-014-0009-0

Cite this article as: Leigh: Alan Feduccia's Riddle of the Feathered Dragons: what reptiles gave rise to birds? Evolution: Education and Outreach 2014 7:9. 